\title{
The Results of New Studies of the Rock-Hewn Churches of the Historical Regions of Endärta and Tämben (Tigray Region, Ethiopia)
}

\author{
Sergey Klyuev ${ }^{1, *}$

\begin{abstract}
${ }^{1}$ Scientific Research Institute of Theory and History of Architecture and Urban Planning, branch of the Central Institute for Research and Design of the Ministry of Construction and Housing and Communal Services of the Russian Federation, Moscow, Russia

*Corresponding author. E-mail: serjklyuvue@yandex.ru
\end{abstract}

\begin{abstract}
The article is devoted to the results of new research carried out in Tigray (Ethiopia) in October 2019. The focus is on rock-hewn churches located in the southern part of the region, in historical areas Tämben and Sähart (Endärta). These are the churches: Wuqro Yohannes Wäldä Nägwädgwad, Abunä Samu'el ${ }^{\circledR}$ Abiy 'Addi and Maryam Gunfan. They belong to different types. According to a number of features, the churches of Yohannes Wäldä Nägwädgwad and Abunä Samu'el 'Abbiy 'Addi seem to be one of the earliest in Tämben. Maryam Gunfan, on the contrary, is the most characteristic of the late cave-type churches for the Sähart (Endärta) area. The purpose of this article is to consider new material collected during the expedition, solving typological issues and dating of these monuments.
\end{abstract}

Keywords: Ethiopia, Tigray, rock-hewn, churches, Endärta, Tämben, Sähart

\section{INTRODUCTION}

During the 2019 expedition to the Tegray region in northern Ethiopia, a number of little known to science churches were explored. Some of them were presented in the scientific literature with only a brief mention. For example, in the large work on the study of rock-hewn churches of Tegray carried out in the 1970s by R. Plant with collaboration of D.R. Buxton and P. Gilkes this churches are only listed [1]. Since then, in special scientific publications, complete information on these churches has not appeared.

Now context have changed. For example, a cavechurch Maryam Gunfan, that previously could not be fully studied, were abandoned, became available for study its sanctuary.

This article discusses three rock-hewn churches located in the southernmost historical areas of Togray: two in Tämben and one in Sähart (鸣ndärta) for some reasons previously not specifically studied. These are the churches: Wəqro Yoḥannəs Wäldä Nägwädgwad, Abunä Samu'el ' Abiy 'Addi, Maryam Gunfan. Each of the churches will be considered here in the context of solving questions of their dating and typological affiliation.

*Project: The article used the results of a study done with financial support from the Russian Foundation for Basic Research: project no. 19-012-00299 A.

\section{WGQRO YOḤANNGS WÄLDÄ NÄGWÄDGWAD}

This church has not been specifically studied before. It was first included in the list of Abba Tewelde Medhin Joseph (1969) [2], then transferred from there to the list of R. Plant (1985) [3] (however, she does not give any information about it, since she did not visit it). In fact, for the first time information about the church was published in 2019 by the collective work "Geo-trekking in Ethiopia's Tropical Mountains" under the direction of geologist J. Nyssen [4]. Here it is referred to under the name "Debre Sema'it".

This church is interesting for its atypical solutions for the plan and decor, which suggests that this is one of the earliest rock-hewn churches in Tämben. The following features are characteristic of most rock-hewn churches of this area: "open plan" (the sanctuary (mäqdäs) is not separated from the nave (qəddəst) by a wall); multiply of mänbärä tabot; equal height of the vaults and prevalence of multi-dome decor in most of the vault cells; the presence in one form or another of a ambulatory; the absence of the Aksumite frieze (its replacement with a frieze of false arches) [5]. According to hagiographic sources, as well as an analysis of architectural features and preserved fragments of paintings, churches of this type date back to the 15 th century [6]. 
Yohannəs Wäldä Nägwädgwad is a not big (approx. $7 * 6.5 \mathrm{~m}$, with max. height in the nave $4 \mathrm{~m}$ ) three-nave basilica, oriented approximately to the northeast ("Fig. $1 ")$. Narthex is absent here, which, presumably, can be associated with its collapse. Probably the closest similarity of the plan is found in a large rock-hewn basilica - Wəqro Maryam (near Näbälät, Amba Śänayti) [7].

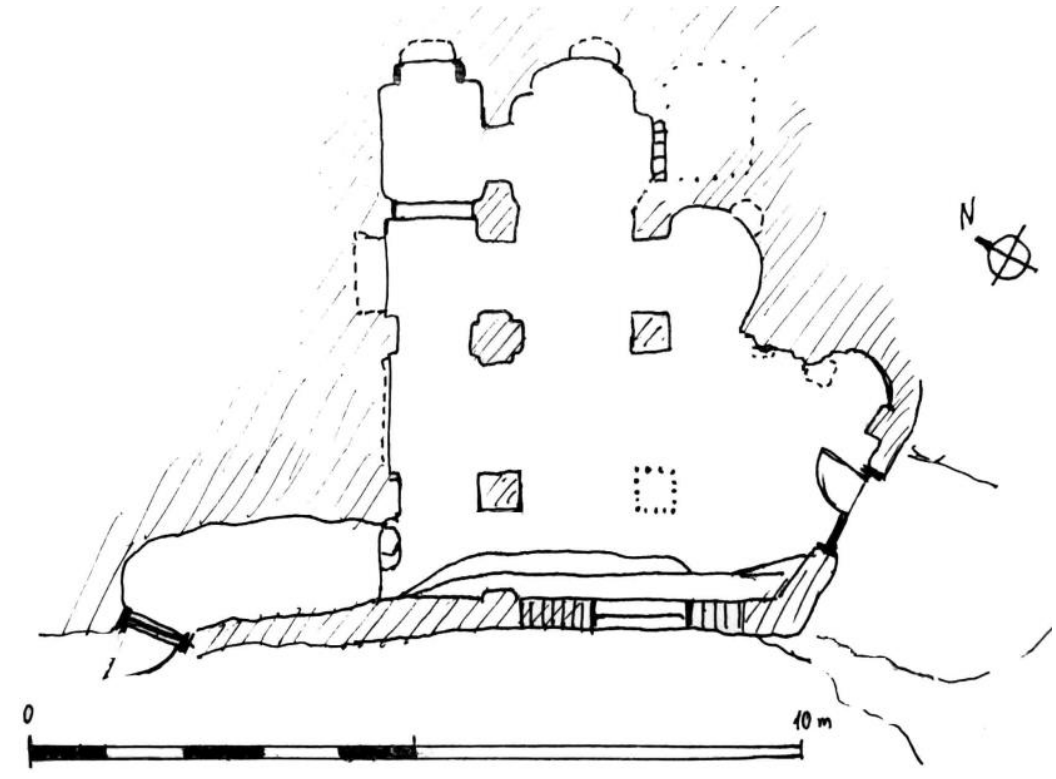

Fig. 1. Plan of Wəqro Yoḥannəs Wäldä Nägwädgwad (Sergey Klyuev).

Signs of similarity there are: 1) the nave vault is also divided into two parts: the west part of the nave vault brings together two cells and it is much higher than eastern part, which consist in one cell. So they are separated by a high pier over the arch. 2) A similar structure of the sanctuary: access to the mäqdäs is possible only through the triumphal arch, the southern pastophoria in Yohannəs Wäldä Nägwädgwad is unavailable, since the passage is blocked by stones; in Wəqro Maryam - it is completely absent, and in the north (where an additional mänbärä tabot is located), passage is carried out only from the central part of the mäqdäs. In both churches into the northern pastophoria from the aisle of qaddest opens not big semicircular window, cut out in the upper part of the wall.

Now we will consider some features of the decoration of the Yohannəs Wäldä Nägwädgwad church:

- The western part of the vault of the nave is close to the so-called saddle-back shape [8]. This constructive form of overlapping the vault was widespread in the period 10th (possibly earlier) 15th centuries in the built churches of both Tegray and Lasta, however, in the rock-hewn churches of Lasta (in particular, Lalibäla) imitations of this construction are unknown [9]. In Togray, it is rather atypical for rock-hewn architecture and most of the examples of it known in northern Togray - the Haramat district and its environs (Iyäsus Gwahəgot (Haramat),
Arba'etu ヨnsəsa 'Addi Ḉwa (Șä'ada ヨmba), Abunä Gäbrä Mika'el Kelele (Haramat), Maryam Siit Agamä (Ganta 'Afäšum), Maryam Bahəra (Haramat)) [10], which, may be due to the location in relative proximity of the revered ancient monastery of Däbrä Damo, in the church of which this structure was preserved for a long time (i.e. it was precisely its forms that they tried to repeat) [11].

- The dome of apsidal sanctuary is deep, decorated with ribs converging to the central ring. One of the closest to this example is the dome, made in the early rock-hewn church (6th10th centuries.) Täklä Haymanot in Hawzen [12]. Perhaps this is an indirect sign of the influence of the Haramat (Hawzien) region on these lands through the image of the revered shrine - the church of the outstanding saint Täklä Haimanot (d. 1313 (?)) [13]. Unlike the large Wəqro Maryam basilica in Amba Sänayti, where the sanctuary rooms are rectangular and decorated along the perimeter with the Aksumite frieze [14], the apse is made here without the Aksumite frieze. This is similar, for example, to Iyäsus Gwahəgot (where the Aksumite frieze is completely absent in the whole church) and Täklä Haymanot Hawzen [15].

- On the vault of the nave, a voluminous cross, inscribed in a circle is cut out, possibly depicting a small dome. A round "boss" is made in the 
center of the cross. Probable distant analogies, given the location, can be found in Maryam Däbrä Qorqor, Bilbäla Qirqos, and also Amanu'el Zala [16].

- The Aksumite frieze does not encircle the entire space of the nave, but is located only on its northern and southern walls ("Fig.2"). Six windows on each side, which probably symbolizes the Apostles. In this case, the false window into which the cross is inscribed on the east side (upper the arch) - probably symbolizes Christ. It should be noted that in the churches of Wəqro Maryam Amba Śänayti and Maryam Bahəra, the Aksumite frieze is placed in the nave not only from the north and south sides [17], but also, unlike Yoḥannəs Wäldä Nägwädgwad, from the west, as well as on the walls of the side naves. Such a solution may be indirectly similar to Giyorgis Däbrä Mä'ar, where, however, instead of the Aksumite frieze, an arched frieze is made [18].

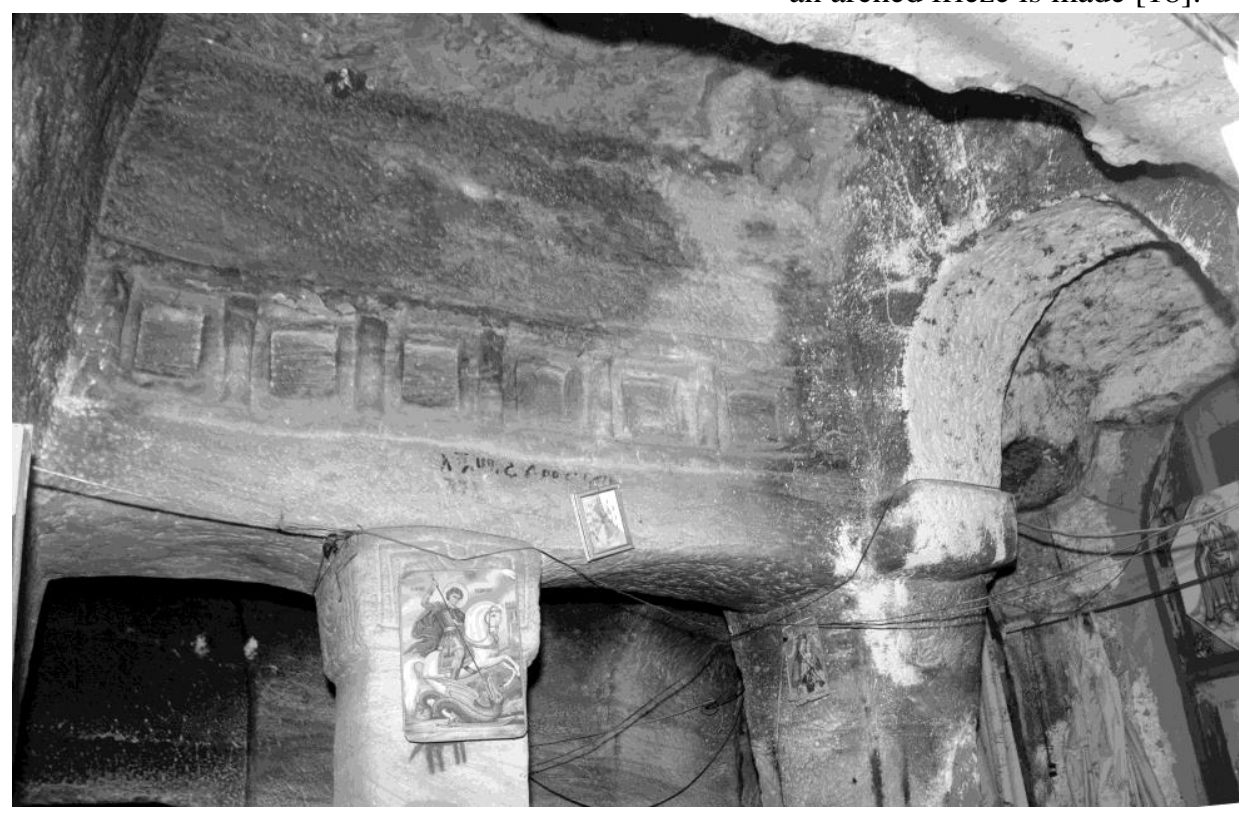

Fig. 2. The nave of Yoḥannəs Wäldä Nägwädgwad church (photograph: Sergey Klyuev)

- Reliefs depicting false windows, with equal crosses inscribed in them. A similar cross or a false window in the form of a cross depicted in the some kilometers to the north Maryam 'Gșəwəto church in the eastern piers of the central nave, above the triumphal arch [19]. The closest analogy is found, again, in the Wəqro Maryam Näbälät church, where a window in the form of a cross is cut into the eastern wall of the nave, leading to the next cell of the nave [20].

- The moldings on the capital of the northwestern pillar is extremely atypical ("Fig.3"). Most likely, the coloring of the stripes in various colors was originally intended. Hypothetically, this decor can go back to the symbolism of preChristian altars for incense, characteristic of the Ethio-Sabean culture [21].

- Decor of arches (triumphal and arches in the southwestern part). These arches are decorated the same way, unlike the others. The decor of these arches is distinguished by a double outstanding archivolt volume. Arches in the rock-hewn churches of Śllase Gundəfru, Giyorgis Däbrä Mäe ar and Maryam Bahəra have some similarities, however, there are no identical ones among them [22].

So, to summarize the signs we can probably date the church to the 14th century (after 1320). That is, by analogy with churches in other areas of Tegray, namely: Wəqro Maryam Näbälät (Amba Śänayti) and Maryam Bahora [23]. This churches belong to the Amba Śänayti and Haramat historical provinces, connected with important rebellion of the ruler of the neighboring 'ㅋndärta, Ya ‘ əbikä Ggzi’ at the first part of the 14th century against the power of the ruler of Abyssinia, 'Amdä Șəyon I (1314 - 1344). The šum (governor) of Tämben did not support Ya'əbikä Hgzi' [24]. 


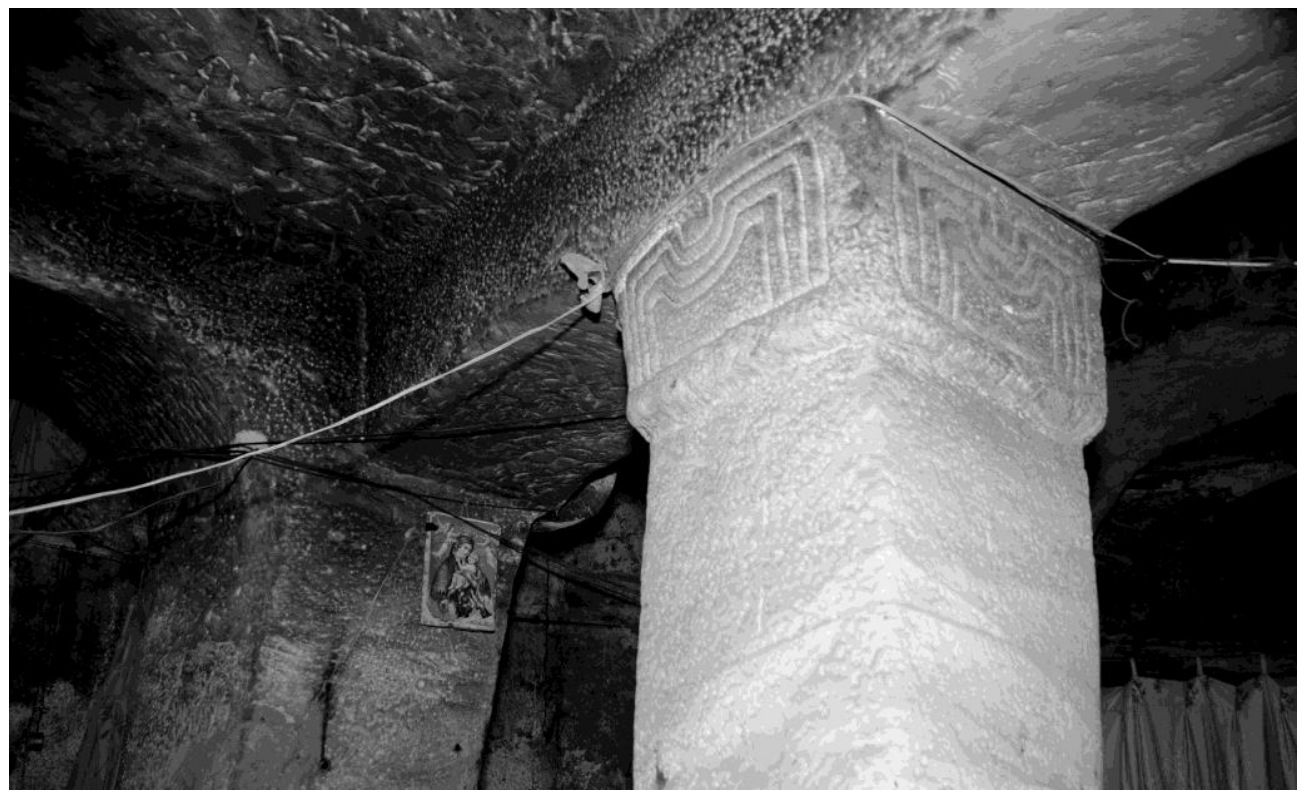

Fig. 3. Capital decoration in Yohannəs Wäldä Nägwädgwad (photograph: Sergey Klyuev).

After the suppression of the rebellion 'Amdä Şəyon's I headquarters was located in Amba Sänayti [25]. Thus, the large, well-decorated, rock-hewn basilica of Wəqro Maryam near the town of Näbälät in Amba Sänayti, with all its appearance pretending to some important symbolic role, is probably associated with the suppression of the uprising and the assertion of the central authority of the ruler over this area. C. Lepage dates it between 1350-1450, that is, the period after the suppression of the rebellion [26].

\section{ABUnÄ SAMU’EL 'ABIY ${ }^{`}$ Addi}

The church, located around the city of 'Abbyi 'Addi, in a rock-hewn slope at a relatively low altitude, near the Tanqwa River, was poorly represented in the scientific literature. R.Plant together with D.R. Buxton in the article of the 1973 year of publishing notes that the church is abandoned and inaccessible [27]. The church cut behind a north-west-facing cliff, along the river bed. Its orientation is somewhat distorted. The church is oriented to the north- or south-east (it is not possible to accurately determine the orientation of the church at the moment when it is not used and there are no mänbära tabot; niches that could mark the direction to sanctuary are carved in both walls).

The interior of the church consists of four cells: a large cell from the north-west (approx. $4.8 * 4 * 3.2$ meters) with a dome of the larger diameter ("Fig. 4"). This room is separated by two wide and relatively low cruciform in section pillars (one of them forms a part of the external facade wall).

On two sides of the central cruciform in section pillar there are arched passages leading to the cells to the southeast. There are three of them, but the southernmost is essentially inferior: it has the wrong truncated plan. In two neighboring cells, separated by high arches, higher vaults (4.7 - 5.5 meters height), each carved a deep semicircular dome. Two types of niches are carved in the north- and southeast walls: rectangular in the frame and semicircular (in the upper part). They repeat the silhouette of arched openings and, probably, can be incomplete passages. The plan of the church is unusual, which can be explained in originally, the church was supposed to have a basilica plan with a multi-domed solution of the vaults (similar to those located also in Tämben: Abba Yohanni, Iyäsus Wälägäsa, Täklä Haymanot Guya, as well as Abunä Yəm'ata Gwəh in Gär'alta [28]), but was never completed.

- On the facade to the south, the Aksumite doorframe is carved, with a characteristic beam above it (false, since it was not completed). Such beams can be found in the churches of the 14th15th centuries: for example, represented on the facade of the built church Maryam Betä Ləhem (in Gayənt) [29].

- The decision of two adjacent cells of the vault in the form of deep semicircular domes without additional decor (ribs, bosses in the central part) may indicate similarities with the churches: Iyäsus Wälägäsa, Maryam Həbə'to, Wəqro Maryam Amba Śänayti [30]. It is most likely that if two lateral rather than central cells are decorated with deep domes, then all cells were planned as domed. That is the church was planned as a multi-domed one, which is a sign of 
the "open type" church, especially widespread in this area.

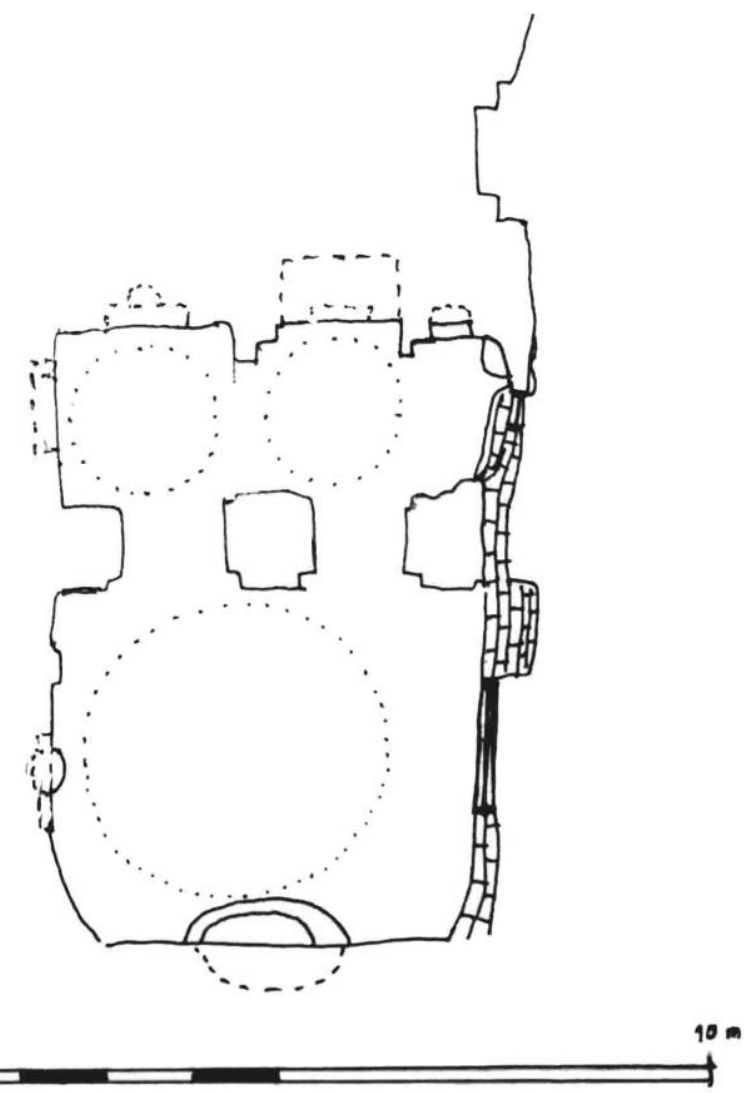

Fig. 4. Plan of Abunä Samu’el `Abiy `Addi (Sergey Klyuev).

In the church, figurative and ornamental murals are fragmentarily preserved, the most notable on two cruciform in section pillars on the side facing the large northwestern cell ("Fig. 5"). The murals are probably dated to the second half of the 14th - early 15th century on the basis of stylistic and iconographic analysis. A wicker ornament with plant motifs, located above the passage between the cruciform in section pillars, the figures (Virgin Mary in the pose of Oranta with the Archangels and the Evangelists (?)) are similar to the paintings of the first cycle in Maryam Däbrä Şəyon (end of the 14th century [31]), some similarities are also found with the paintings in Maryam Bahora (beginning of the 15th century) [32], but the greatest resemblance is to the murals in Giyorgis Däbrä Mä ar (late 14th - early 15th centuries) [33]. However, in these examples there are no multiple images of diagonal crosses. "X-shape" crosses decoration can be found, for example, in the miniatures of manuscripts, such as of the Gospel of Gabrə'el church of Kebran (dates 1412) [34].
Large crosses that divide the image into four sections are similar, in particular, to the picture on the flip side of the icons of the 15 th century [35]. The type of painting, its structure with the numerous crosses, segmenting space, the motive of diagonal crosses, reveals similarities to the subjects of the carved decor of the vaults in the Wəqro Maryam, Amba Sänayti [36]. On the upper part of the walls are double lines of red and green in black outline, which is somewhat similar to the painting in the Betä-Golgota Lalibäla church [37].

So, this church has an unusual plan, since it was obviously not completed. According to a number of signs: a monolithic Aksum portal with a characteristic beam above it, deep domed vaults without additional carved decor, located in adjacent cells, this monument resembles the churches of Woqro Maryam Amba Sänayti (including the structure of decor and murals), as well as Iyäsus Wälägäsa and Abba Yoḥanni and probably dates from the end of 14 th century. 


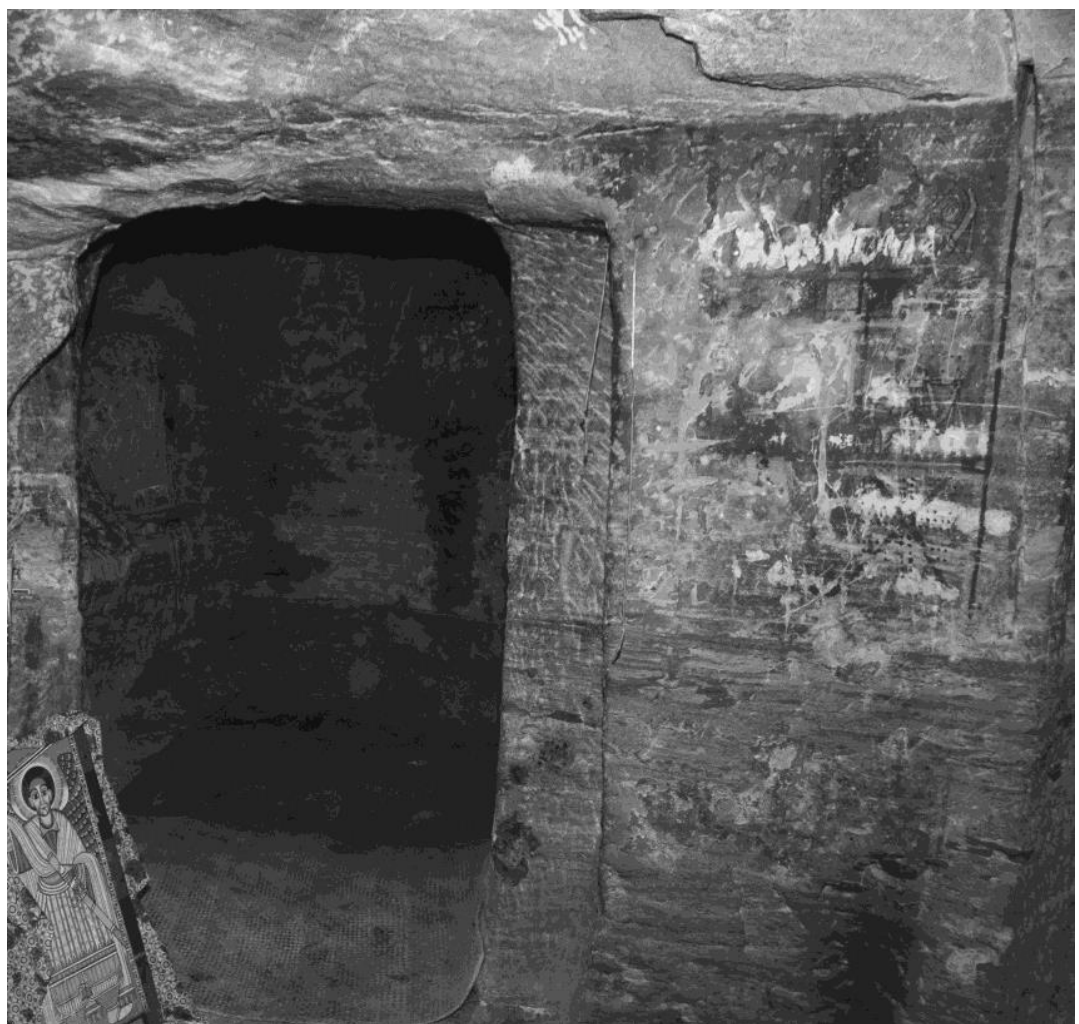

Fig. 5. Cross-sectioned pillar with fragments of paintings (left). Abunä Samu’el ` Abiy `Addi (photograph: Sergey Klyuev).

\section{IV. 吗NDÄRTA: MARYAM GUNFAN}

The plan of the church, now abandoned, is a threepart structure ("Fig. 6"). In fact, the plan of the church reflects the tripartite alignment form (when the three liturgical zones are arranged sequentially one after another) of the one-nave churches, which are something between the basilicas and centric churches. Among the built churches, these are the churches: Däbrä Bərhan Śllase in Gondär (early 19th century), the churches of Lake Tana: Däga Bsțifanos and Țana Qirqos (19th (?) century), Abba Pänțälewon in Aksum (beginning of 20th century) [38].

However, the cave nature of the church Maryam Gunfan made some adjustments to the specifics of its plan: the mäqdäs is shifted towards the east, thereby distorting the alignment of the plan composition. In the church in situ, a small stone-built mänbära tabot was discovered ("Fig. 7"). It is located at the very edge of the step, determinating liturgical zones.

The murals are fragmentary and poorly preserved on the mäqdäs wall. And probably date from the first half of the 20th century. They depict various saints, such as equestrian saint (St.George?).

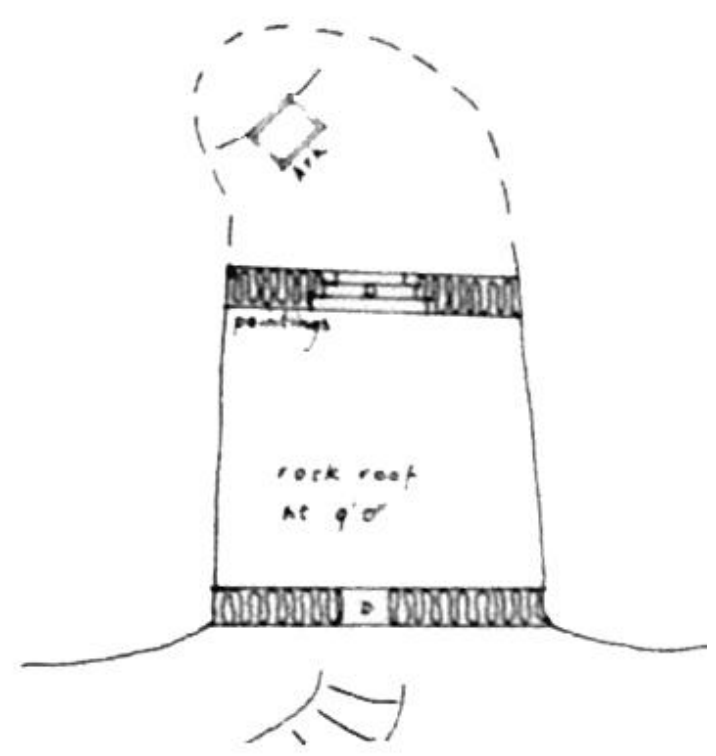

Fig. 6. Plan of Maryam Gunfan (after R.Plant 1985, with addition of S.Klyuev) [39].

Since this church is a cave church, it is difficult to give an exact dating - in which century using of its natural forms for religious purposes started. The 
structure of the mäqdäs wall with fragments of paintings preserved in the church can be dated to the first half of the 20th century (until the beginning of 1970s, when R. Plant visited the church) [40].

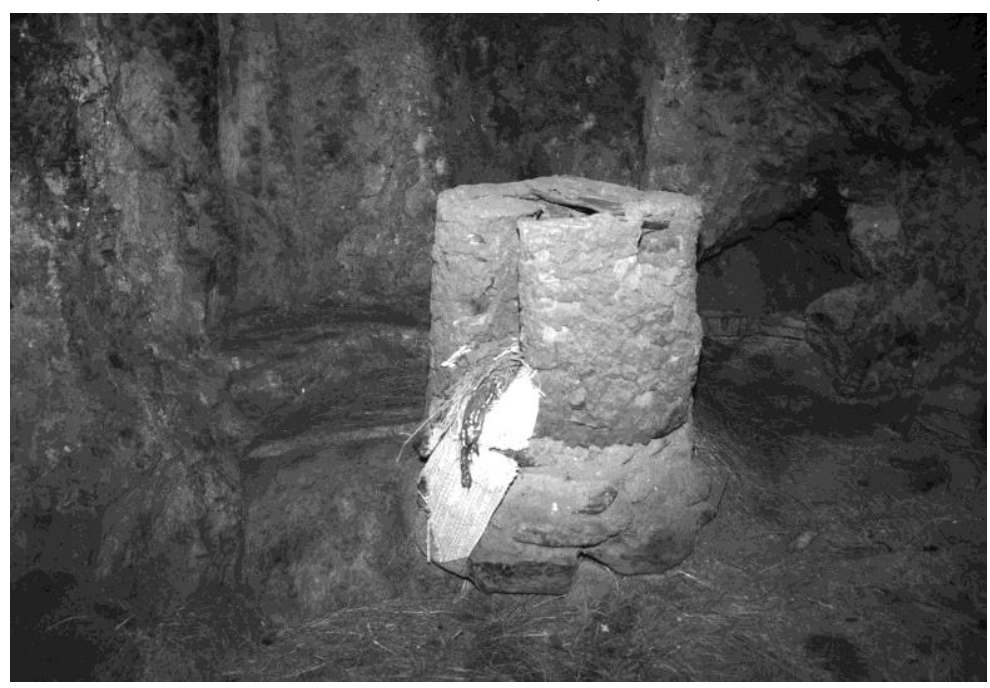

Fig. 7. Mänbära-tabot at the Maryam Gunfan cave-church (photograph: Sergey Klyuev).

Among similar churches, also investigated during the expedition, we distinguish two: Yohannəs Mäțməq Koholo (in the Mäqälä region) [41] and Mika'el Gawi (the region of Säläwa, but geographically located relatively close) [42]. Both are "cave" types, the first has a more complicated plan, and the second, on the contrary, is simpler. Yohannəs Mäțməq Koholo, located near the town of Mäqälä in 啰ndärta, also occupies a natural cave formation in tufa slope. It is partially built: western wall made by stones, but a pair of central pillars are carved from the rock. The space divided here in three liturgical zones by raising of the floor level, the mäqdäs is also three-part, two pastophoria adjoin the central cell of sanctuary. Here preserved paintings of the 17th century [43]. Presumably, this church can be dated to the late 15th-17th centuries. Mika'el Gawi church, located to the south from Gunfan previously not specifically investigated [44]. Our expedition visit it in October 2019. It is currently abandoned. It is a simple grotto-plan with flat vault of the same hight, with a built-in external wall and a fragmentary preserved wall separating the mäqdäs. Very simple forms, murals not preserved. This church is hidden behind the large surface built church used today and now used by community like some storage. It is very difficult to date.

\section{Conclusion}

The two rock-hewn churches of the Tämben region considered in the work: Yoḥannəs Wäldä Nägwädgwad in the area of Agbä, in Doggw'a Tämben and Abunä Samu'el ' Abiy 'Addi are different from the widespread basilica of 'open type' in this region, and are probably chronologically preceded by it. According to a number of signs, they date back to the 14th century. They retain some of the signs of the 'classical' early basilicas, but at the same time, they already demonstrate a significant departure from strict rules. In separate features, they are similar to the rock-hewn churches of the Haramat region and the Amba Sänayti district. What may be hypothetically connected with the history of 'Amdä Şyon's suppression of the uprising of the sum of '马्gndärta Ya'əbikä Ggzi' at the beginning of the 14th century, which was not supported by the šum of Tämben [45]. It is also possible the influence of the Gär'alta region, the monasteries of the Gwostateans movement, namely, Däbrä Mä'ar and its community leader Saint Gäbrä Mäsqäl, who maybe visited closely located Sähart in 14th century [46].

The Maryam Gunfan church in Sähart is probably of late time and late type (with some distortions of the plan caused by its adaptation to the natural forms of the cave). Such a type is characteristic of this area, which is connected with the peculiarities of local political and church history, geology and other natural conditions. Probably, the natural conditions were more conducive to the construction of built churches than to the creation of rock-hewn ones. However, the numerous periods of rebellions and the general decline of this region have not preserved to our days ancient churches. Also natural caves are found here, contributed to the emergence of this particular type of rock churches here.

\section{References}

[1] D.R. Buxton and R. Plant, Rock-hewn churches of the Tigre province [by R.P.] with additional churches [by D.R.B.], in Ethiopia Observer, 1970, vol.13, pp. 157-268; R. Plant, Notes on 17 Newly-discovered Rock-hewn Churches of the Tigre 
(Ethiopia), in Ethiopia Observer, 1973, vol.16, no.1, pp. $36-$ 53.

[2] J. Tewelde Medhin, Introduction générale aux églises monolithes du Tigrai, in Proceedings of the Third International Conference of Ethiopian Studies, vol. 1 Addis Ababa, 1969, p.97.

[3] R. Plant, Architecture of the Tigre, Ethiopia. Worchester, Ravens Educational and Development Services Publ., 1985, p.33.

[4] J. Nyssen, M. Jacob and A. Frankl, Geo-trekking in Ethiopia's Tropical Mountains. The Dogu'a Tembien District. GeoGuide. Basel: Springer Nature Switzerland AG Publ., 2019.

[5] D. R. Buxton, The rock-hewn and other medieval churches of Tigre Province, Ethiopia, in Archaeologia, vol. 103, 1971, pp. 58-68; D.W. Phillipson, Ancient churches of Ethiopia: fourthfourteens centuries. New Haven [Conn.], London, Yale University Press Publ., 2009, p.192.

[6] D. R. Buxton, The rock-hewn and other medieval churches of Tigre Province, Ethiopia, in Archaeologia, vol. 103, 1971, pp. $58-68$

[7] G. Gerster, Churches in Rock. London, Phaidon Publ., 1970, p.127.

[8] E. Balicka-Witakowska and M. Gervers, Yəmrəhannä Krəstos, in Encyclopaedia Aethiopica, vol.5: Y-Z, Ed. by A.Bausi, S. Uhlig. Wiesbaden, Harrassowitz Publ., 2014, p.55.

[9] R. Plant, Architecture of the Tigre, Ethiopia. Worchester, Ravens Educational and Development Services Publ., 1985; M. Di Salvo, The Basilicas of Ethiopia. An architectural History. London-New York, I. B. Tauris Publ., 2017, pp.100-133.

[10] R. Plant, Architecture of the Tigre, Ethiopia. Worchester, Ravens Educational and Development Services Publ., 1985, pp.125, 167-168, 183,186,189.

[11] D. R. Buxton, The Christian antiquities of northern Ethiopia, in Archaeologia, vol. 92, 1947, pl.II-d.

[12] M. Di Salvo, The Basilicas of Ethiopia. An architectural History. London-New York, I. B. Tauris Publ., 2017, pp.70-71.

[13] D. Nosnitsin, Täklä Haymanot, in Encyclopaedia Aethiopica, vol.4: O-X, Ed. by S. Uhlig.Wiesbaden, Harrassowitz Publ., 2010, pp.831-834

[14] D.W. Phillipson, Ancient churches of Ethiopia: fourth-fourteens centuries. New Haven [Conn.], London, Yale University Press Publ., 2009, pp.102-104.

[15] R. Plant, Architecture of the Tigre, Ethiopia. Worchester, Ravens Educational and Development Services Publ., 1985, pp.186-187; M. Di Salvo, The Basilicas of Ethiopia. An architectural History. London-New York, I. B. Tauris Publ., 2017, pp.70-71.

[16] D. R. Buxton, The Christian antiquities of northern Ethiopia, in Archaeologia, vol. 92, 1947, pl. IX-b; C. Lepage and J. Mercier, Les eglises historiques du Tigray (The ancient churches of Tigrai). Paris, ADPF Publ., 2005, pp.116-117; R. Plant, Architecture of the Tigre, Ethiopia. Worchester, Ravens Educational and Development Services Publ., 1985, p.73.

[17] R. Plant, Architecture of the Tigre, Ethiopia. Worchester, Ravens Educational and Development Services Publ., 1985, pp.77, 183.

[18] E. Balicka-Witakowska, Däbrä Mä`ar, in Encyclopaedia Aethiopica, vol. 2: D-Ha, Ed. by S. Uhlig. Wiesbaden, Harrassowitz Publ., 2005, pp. 29-31.

[19] R. Plant, Architecture of the Tigre, Ethiopia. Worchester, Ravens Educational and Development Services Publ., 1985, p.160.

[20] D.W. Phillipson, Ancient churches of Ethiopia: fourth-fourteens centuries. New Haven [Conn.], London, Yale University Press Publ., 2009, pp.102-103.
[21] A. Caquot and A. J. Drewes, Les Monuments Recueillis à Maqallé (Tigré), in Annales d' Éthiopie, vol. 1, Paris, 1955, pp. 26-32.

[22] M. Di Salvo, The Basilicas of Ethiopia. An architectural History. London-New York, I. B. Tauris Publ., 2017, p.66; D R. Buxton, The rock-hewn and other medieval churches of Tigre Province, Ethiopia, in Archaeologia, vol. 103, 1971, pl.XXVIII; C. Lepage and J.Mercier, Les eglises historiques du Tigray (The ancient churches of Tigrai). Paris, ADPF Publ. 2005, p. 144.

[23] C. Lepage and J. Mercier, Les eglises historiques du Tigray (The ancient churches of Tigrai). Paris, ADPF Publ., 2005, pp.140-145,160-163.

[24] D. Nosnitsin, Ya`əbikä Ggzi’, in Encyclopaedia Aethiopica, vol.5: Y-Z. Ed. by A.Bausi, S. Uhlig.Wiesbaden, Harrassowitz Publ., 2014, p.5; A. Bausi, Tämben. Early history of Tämben to 17th century, in Encyclopaedia Aethiopica, vol.4: O-X, Ed. by S.Uhlig, A.Bausi. Wiesbaden, Harrassowitz Publ., 2010, pp. 852-853.

[25] J. Mantel-Niećko and D. Nosnitsin, 'Amdä Səyon I, in Encyclopaedia Aethiopica, vol.1: A-C, Ed. by S. Uhlig. Wiesbaden, Harrassowitz Publ., 2003, p.227.

[26] C. Lepage and J. Mercier, Les eglises historiques du Tigray (The ancient churches of Tigrai). Paris, ADPF Publ., 2005 p.162.

[27] R. Plant, Notes on 17 Newly-discovered Rock-hewn Churches of the Tigre (Ethiopia), in Ethiopia Observer, 1973, vol.16, no. 1, p.49.

[28] R. Plant, Architecture of the Tigre, Ethiopia. Worchester, Ravens Educational and Development Services Publ., 1985 pp.73, 156-157,161.

[29] G. Gerster, Churches in Rock. London, Phaidon Publ., 1970, p. 140 .

[30] R. Plant, Architecture of the Tigre, Ethiopia. Worchester, Ravens Educational and Development Services Publ., 1985 pp.77, 161-162.

[31] E. Balicka-Witakowska, Churches of Däbrä Şəyon, in Encyclopaedia Aethiopica, vol. 2: D-Ha, Ed. by S. Uhlig. Wiesbaden, Harrassowitz Publ., 2005, pp. 42-43.

[32] C. Lepage and J. Mercier, Les eglises historiques du Tigray (The ancient churches of Tigrai). Paris, ADPF Publ., 2005, p.140.

[33] E. Balicka-Witakowska, Däbrä Mä ar, in Encyclopaedia Aethiopica, vol. 2: D-Ha, Ed. by S. Uhlig. Wiesbaden, Harrassowitz Publ., 2005, pp. 29-31.

[34] J. Leroy, S. Wright and O.A. Jäger, Ethiopia. Illuminated Manuscripts. New York, New York Graphic Society Publ. 1961, pl.VIII-XIX

[35] S. Chojnacki, Ethiopian Icons. Catalogue of the Collection of the Institute of Ethiopian Studies, Addis Ababa University. Milano, Skira Publ., 2000, cat. 146.

[36] M. Di Salvo, The Basilicas of Ethiopia. An architectural History. London-New York, I. B. Tauris Publ., 2017, p.77.

[37] C. Lepage and J. Mercier, Lalibela, Wonder of Ethiopia: The Monolithic Churches and their Treasures. London, Pau Holberton Publ., 2012, p.113.

[38] M. Di Salvo, Churches of Ethiopia. The Monastery of Narga Sellase, with texts by Stanislaw Chojnacki, Osvaldo Raineri. Milano, Skira Publ., 2000, pp.67-69.

[39] R. Plant, Architecture of the Tigre, Ethiopia. Worchester, Ravens Educational and Development Services Publ., 1985, p.85.

[40] R. Plant, Notes on 17 Newly-discovered Rock-hewn Churches of the Tigre (Ethiopia), in Ethiopia Observer, 1973, vol.16, no. 1, pp. $43-44$. 
[41] D. Nosnitsin, Ethio-SPaRe. Cultural Heritage of Christian Ethiopia: Salvation, Preservation and Research. Third Mission, April-May 2011. Report / European Union Seventh Framework Programme IDEAS ERC Starting Grant. Hamburg, Hamburg University Publ., 2011, pp.2-6.

[42] R. Plant, Notes on 17 Newly-discovered Rock-hewn Churches of the Tigre (Ethiopia), in Ethiopia Observer, 1973, vol.16, no.1, p. 45.

[43] D. Nosnitsin, Ethio-SPaRe. Cultural Heritage of Christian Ethiopia: Salvation, Preservation and Research. Third Mission, April-May 2011. Report / European Union Seventh Framework Programme IDEAS ERC Starting Grant. Hamburg, Hamburg University Publ., 2011, p.4.

[44] W. Smidt and R. Pankhurst, Säläwa, in Encyclopaedia Aethiopica, vol. 4: O-X, Ed. by S. Uhlig. Wiesbaden, Harrassowitz Publ., 2010, p. 492.

[45] A. Bausi, Tämben. Early history of Tämben to 17th century, in Encyclopaedia Aethiopica, vol.4: O-X, Ed. by S. Uhlig, A.Bausi.Wiesbaden, Harrassowitz Publ., 2010, pp. 852-853.

[46] G. Fiaccadori, Ewosțateans, in Encyclopaedia Aethiopica, vol.2: D-Ha, Ed. by S. Uhlig.Wiesbaden, Harrassowitz Publ., 2005, pp. 464 - 469. 